\title{
Peace Building Activism of Millennial Santri Communities through Social Media: A Nethnography Study
}

\author{
M Sobirin ${ }^{1}$, H Muhammad $^{2}$, M K Zuhri ${ }^{3}$ \\ Faculty of Ushuluddin and Humanities, UIN Walisongo Semarang ${ }^{1,2,3}$ \\ \{mohamadsobirin@walisongo.ac.id ${ }^{1}, \underline{\text { hasyimmuhammad@,walisongo.ac.id }}{ }^{2}, \underline{\text { mishbah@walisongo.ac.id }}{ }^{3}$ \}
}

\begin{abstract}
This research is dedicated to answering the questions; how do the santri communities perform the practice of peacebuilding on social media? And how do they respond to propaganda based on religious extremism on social media? By using nethnography approach, this study found that they have performed peacebuilding activism within the social media sphere by producing moderate discourses and countering radical doctrines. There are 3 main topics of discourses; a. Moderate Sunnitheology doctrines and anti-hate speech discourses, b. Religious based tolerance and multiculturalism discourses, and c. Universal peaceful discourses. Although the strategies to express the discourses are different, but the driving factor to produce discourses generally is similar; their awareness in response to religious discourses within social media that has been overly dominated by Anti-Aswaja propaganda, radical doctrines, and Islamism that seek to replace Pancasila with Islam as Indonesia's constitution.
\end{abstract}

Keywords: Peace Building, Santri, Social Media,

\section{Introduction}

Freedom of expression is the most important part of human rights. Its existence is very strategic in hitching the road and working democracy. It is hard to imagine a democratic system working without freedom of expression, attitude, and expression. In this regard, it is relevant to point out here that Lord Steyn views that "Freedom of expression is, of course, intrinsically important. Freedom of speech is the lifeblood of democracy".

Problems arise when freedom of expression guaranteed and protected by the constitution is not based on the values of harmony and public civilization. The expressions "Religion are the Source of Conflict" are verified significantly when we watch hate speech scenes on social media (Facebook, Twitter, Instagram, etc.), and see profiles of the perpetrators of hate speech and persecution on social media.

Santri communities as part of this nation feel responsible for the above ironic digital phenomenon. Therefore, they try to bring politeness of expression in social media through efforts to build peace within the sphere. This can be noted in the last three years, with the emergence of social media accounts of santri who are active in enlivening the online media 
space with a campaign of politeness of expression and a call for peace on all the differences underlying the debate and disputes among netizens.

There are 3 social media accounts that become the object of this research, i.e.Santri Sidogiri, Ala Santri, and Santri Gus Dur. The selection of these three accounts is not only based on the activism of those who campaign for religious tolerance in digital media but also depended on the frequency of their activeness in social media with aa large number of discourses produced through status posting. Although all three are present on several social media platforms, Facebook is the one they use most often, so this research only focuses on their digital activity on Facebook.

Based on the background above, this research is aimed at uncovering the practice of peaceful community activism through discourse production carried out by the 3 santri communities within social media, both in terms of the content produced, the strategies used, and the driving factors.

\section{Method}

\section{Netnography as An Approach}

The approach used in this research is a qualitative approach with Netnography theory. There are various names pinned on anthropology sub-disciplines that study culture and online communities, starting from the term webnography, virtual ethnography, digital ethnography, and cyber anthropology with various nuances and paradigm spectrum [1]. Netnography is an approach is built on ethnography. Ethnography, which was born from anthropology determines the object of its study in the reality of human life, which is intended to reveal information related to the object in detail which in Geertz language is called (1973) 'thick descriptions'[2]. Piia Varis emphasizes the importance of ethnography as an approach to cultural studies in digital or online media,

"Ethnography, as a holistic approach to societies and cultures, can make a substantial contribution to the study of present-day digital communication environments and our digital culture(s)." [3].

The most authoritative scholar in the study of culture and online communities is Robert V. Kozinets who has written many books on netnography. One of Kozinets's most poignant works is entitled Netnography: Doing Ethnographic Research Online published in 2009. The book stated that online communities form and embody the values, customs, and beliefs that govern and direct the behavior of the community [4]. In short, although the social interaction of online community members is computer-mediated, online communities shape a culture. All forms of human culture are the subject of anthropological talk.

Our next problem is, what is the online community that is the "location" of our netnographic research? Following Howard Reingold's definition in the book Virtual Community: Homesteading on the Electronic Frontier, the online community is:

"Social aggregations that emerge from the net when enough people carry on...public discussions long enough, with sufficient human feelings, to formwebs of personal relationships in cyberspace" [1]. 
Through the above understanding, we can draw some restrictions regarding online communities: communities are collective with the interaction of individuals who are computer-mediated, have symbols exchanged by at least 20 people (the minimum limit made by Kozinets) and this exchange can be accessed by researchers, where these online interactions act like ongoing relationships and involve human feelings so as to produce a social network with a shared identity. Thes limitations created by Kozinets are quite useful for us to identify the online community that is about to be studied. When we have found a community of choice, the next step is to find out how we will conduct ethnographic research through the internet [4].

The stages of digital ethnographic research are almost similar to the stages of traditional ethnography. The initial stage begins with setting boundaries of research and making questions, selecting online communities, participating in observation, followed by analyzing data and presenting our ethnographic report. In terms of substance, traditional ethnography and netnography are not much different. Before discussing the differences between these two things, what is netnography? In the book Netnography, Kozinets mentioned that netnography is defined as "a form of ethnography that was adapted for a device-mediated social world of computer". In short, netnography is a method for studying cybernetics space (cyberspace). Lately, netnography has been promoted as the only method specifically designed to study culture and online communities [5].

In netnography, the data are mainly obtained from the hypertext interactions of netizens. The advantages of the hypertext format, all forms of symbol exchange in the form of text, sound or images can be stored in the original format, so that the meaning of recording data also shifts. In netnography, jotting and transcripts are no longer necessary. As explained in the first part of the paper, anthropologists can now analyze data and display ethnographic reports in the form of hypertext (hypermedia).

A few of discussion is taken about data analysis and hypertext writing. Because of its multilinear nature, the research process is no longer chronological. Data documents and analysis documents can be interlocked so that the boundaries between data and analysis are blurred. In the analysis phase, the use of thinking frameworks and theories in netnography will depend as much on the anthropologist's decision, as in ordinary ethnography. The latest online ethnography is very participatory and democratic, so reading texts can be very fluid. Even so participatory and democratic, the reader can shift the researcher in building discourse about cultural representation.

\section{Data Collection and Limitation}

The research method that I use in this research is descriptive-analytical because this research is to explain events. The study was conducted to obtain a digital empirical picture of how the understanding of the santri community that manages social media accounts for peacebuilding, as well as how peacebuilding practices they do on social media through the production of knowledge and discourse. To uncover the data, I conducted digital observations and interviews with research subjects.

Data collection methods in this study were interviews and observations.

(1) Interviews were conducted to uncover the motives, strategies, and motivations of the santri community in conducting peacebuilding on social media. Interviews were conducted with research subjects, namely 3 social media accounts managed by the santri community; 1 . Santri Sidogiri, 2. Ala Santri, and 3. Santri Gus Dur. 
(2) Observations obtained through observations digitally of the posts of 3 santri social media accounts uploaded from 2015 to 2018, in which there are 10 thematic keywords applied, i.e.: toleransi, damai, harmoni, tasamuh, moderat, NKRI, Bhineka, santun, ramah, and kemanusiaan.

In conducting research, data is needed from certain sources that are in accordance with the needs and research problems. As stated by Nana Sudjana and Ibrahim that, "the population is the entire source of data which is possible to provide useful information for research problems" [6]. Populations can be people, values, goods or other objects that can be used as research objects. As for the population in this study are 3 social media accounts managed by the santri community as I have mentioned above.

\section{Result and Discussion}

\section{Profile of 3 Accounts and Quantity of Discourse Production}

As I mentioned in the previous section, there are three social media accounts using the Facebook platform managed by the santri community, in this section, I describe the profiles of the three and their digital activities in seeking peacebuilding on digital media. The activity is described by a thematic and quantitative approach by looking at the compatibility of their potential content with 10 keywords that I specify and counting the amount. The following is a detailed explanation:

\section{Santri Sidogiri}

Santri Sidogiri is an official account created by Sidogiri Islamic Boarding School to support its da'wah in the midst of millennial Muslim communities, and specifically to promote Sidogiri Islamic boarding schools to the community. This account was also made in the context of community service and the State, where matters relating to how a Muslim should live as a nation and state are also taught here. This account was created on July 23, 2016, by santri Pondok Pesantren Sidogiri, having its address at Kraton, Sidogiri, Pasuruan. Santri Sidogiri has 29,933 followers and 28,191 people like it.

This account alludes to many matters relating to peace building and humanity. The following is a description of the quantitative statistics of these account posts from 2015-2018:

Table 1. Keywords of Peace in Santri Sidogiri Account

\begin{tabular}{llc}
\hline Keywords of Peace Building & Date of Post & Quantity Post \\
\hline Toleran/Toleransi & - & 0 \\
Damai/Perdamaian & - & 0 \\
Harmoni & October 22, 2017 & 1 \\
Tasamuh & - & 0 \\
Moderat/Moderasi & - & 0 \\
NKRI & 2015 (2 kali) & 12 \\
& $2016(2$ kali) & \\
& 2017 (5 kali) & \\
Bhineka & 2018 (3 kali) & 0 \\
Santun & - & 0 \\
Ramah & - & 1 \\
Kemanusiaan & January 14, 2018 & 0 \\
Total Number of Post (2015-2018) & - & 14 \\
& & \\
\hline
\end{tabular}




\section{Ala Santri}

This account is very active and has quite a large following, especially among the santri. This account publicizes a lot of santri activities in Islamic boarding schools, how it should be a good santri through various activities such as seminars, online discussions, workshops and so on. This account was created on November 25, 2014, by an anonymous email address alasantri25@gmail.com. Ala Santri has 93,940 followers and is liked by 92,707 people.

Ala Santri's Admin is scattered in several Islamic boarding schools in Indonesia. However, they are connected to each other through private groups on Whatapps to coordinate and contribute to one another. Each social media account has one coordinator who is fully responsible for the content and also the sustainability of the account. All managerial matters are regulated by the daily board so as not to interfere with the admin in processing content to be posted.

Ala Santri is an account that actively campaigns for the role of the santri in maintaining the peace of the country. Therefore, there are many posts aimed at creating peace founded within this account's posts. The following is a description of the quantitative statistics of these account posts from 2015-2018:

Table 2. Keywords of Peace in Ala Santri Account

\begin{tabular}{llc}
\hline Keywords of Peace Building & Date of Post & Quantity of Post \\
\hline Toleran/Toleransi & & 0 \\
Damai/Perdamaian & $2015(2$ times $)$ & 12 \\
& $2016(5$ times $)$ & \\
Harmoni & $2017(3$ times $)$ & 0 \\
Tasamuh & $2018(2$ times $)$ & 0 \\
Moderat/Moderasi & - & 2 \\
NKRI & - & 26 \\
& 17 Juli 2017 & \\
Bhineka & 21 Juli 2017 & \\
Santun & $2015(8$ times $)$ & 1 \\
& $2016(7$ times $)$ & 4 \\
Ramah & $2017(6$ times $)$ & 5 \\
Kemanusiaan & $2018(5$ times $)$ & 4 \\
Total Number of Post (2015-2018) & 28 Juli 2017 & \\
& $2016(3$ times $)$ & 60 \\
\hline
\end{tabular}

\section{Santri Gus Dur}

Santri Gus Dur is an account that is used as a forum for campaigning tolerance and peace, especially those originating from the opinions of a great ulama' named $\mathrm{KH}$. Abdurrahman Wahid or often called Gus Dur. This account was created on April 29, 2014, by the Gusdurian community in the Special Region of Yogyakarta. Currently, Santri Gus Dur has 11,071 followers and 11,058 like this account. Santri Gus Dur is an account created by the Gusdurian 
community so that what is then campaigned for are the arguments taken from a Gus Dur, where Gus Dur's figure as we know, that he is one of the figures who always echo tolerance and live peacefully in diversity. Therefore, the majority discourse of this account is indeed the emphasis on tolerance.

The following is a description of the quantitative statistics of these account posts from 2015-2018:

Table 3. Keywords of Peace in Santri Gus Dur Account

\begin{tabular}{|c|c|c|}
\hline Keywords of Peace Building & Date of Post & Quantity of Post \\
\hline Toleran/Toleransi & $\begin{array}{l}2015 \text { ( } 1 \text { time }) \\
2016 \text { (3 times) } \\
2017 \text { (3 times) }\end{array}$ & 7 \\
\hline Damai/Perdamaian & $\begin{array}{l}2015 \text { (5 times) } \\
2016 \text { (2 times) } \\
2017 \text { (6 times) } \\
2018 \text { (4 times) }\end{array}$ & 17 \\
\hline Harmoni & $\begin{array}{l}2015 \text { (4 times) } \\
2017 \text { (2 times) }\end{array}$ & 6 \\
\hline Tasamuh & March 29, 2017 & 1 \\
\hline Moderat/Moderasi & $\begin{array}{l}2016 \text { (3 times) } \\
2017 \text { (3 times) }\end{array}$ & 6 \\
\hline NKRI & $\begin{array}{l}\text { April 24, } 2016 \\
\text { April 21, } 2017 \\
\text { April 1, } 2015\end{array}$ & 3 \\
\hline Bhineka & - & 0 \\
\hline Santun & $\begin{array}{l}\text { July } 1,2015 \\
\text { September } 9,2016 \\
\text { June } 5,2017\end{array}$ & 3 \\
\hline Ramah & $\begin{array}{l}2015 \text { (2 times }) \\
2016 \text { (3 times) } \\
2017 \text { (4 times }) \\
2018 \text { ( } 1 \text { times })\end{array}$ & 10 \\
\hline Kemanusiaan & $\begin{array}{l}2015 \text { ( } 7 \text { times }) \\
2016 \text { (5 times) } \\
2017 \text { (10 times }) \\
2018 \text { (10 times })\end{array}$ & 32 \\
\hline \multicolumn{2}{|c|}{ Total Number of Post (2015-2018) } & 79 \\
\hline
\end{tabular}

\section{Discourse Production as a Strategy for Peace Building}

I did an analysis of the discourses produced by the 3 santri communities above in striving for the creation of a peaceful life on social media, by observing the discourse they produced from 2015 to 2018. This analysis was carried out with a keyword-based thematic approach to the discourse they publish and disseminate through managed accounts. There are 10 keywords that I use in this research to get the primary data analyzed, namely toleransi, damai, harmoni, tasamuh, moderat, NKRI, Bhineka, santun, ramah, and kemanusiaan.

Meanwhile, in order to analyze the strategies and motives behind them in peaceful community activism in the digital world, I obtained interviews with related parties who manage the 3 social media accounts. 


\section{Santri Sidogiri; Aswaja's Theological Discourse and Anti-Hate Speech}

The discourse produced by Santri Sidogiri's account revolves around strengthening Aswaja's theology in the midst of the onslaught of takfiri theology which is often incited with propaganda syirk, bid'ah, khurafat, and tagut; and instilling a critical attitude towards hate speech and hoax news aimed at dividing the unity of the nation.

First, strengthening Aswaja's theology. Santri has a strong militancy in defending the ideology they believe in. This conviction motivated the Santri Sidogiri community to oppose and dispel the theology that potentially carries violence. Therefore, Santri Sidogiri explicitly declared himself as the account that is responsible for maintaining and defending the beliefs of Ahlussunnah Wal Jamaah with peaceful Islamic values and respecting differences. This was stated in a posting dated June 10, 2018,

"We must be at the forefront in defending Ahlusunnah Wal Jamaah and fighting deviant notions. Whatever the risks, we will continue to live firmly, because that is one of the main objectives of the Pondok Pesantren Sidogiri. Namely, guiding people to have good faith and do good deeds."

Second, inculcation of a critical attitude towards hate speech and hoax news. One of the posts related directly to this is entitled "Be Wise Alumni":

"There are many hate speeches campaigned to our Islamic boarding school (Sidogiri), no need to worry, let alone tremble. We must beat the forefront in defending Ahlusunnah Wal Jamaah and fighting deviant notions. Whatever the risks, we will continue to live firmly, because that is one of the main objectives of the Pondok Pesantren Sidogiri. Namely, guiding people to have good faith and do good deeds. Sidogiri teaches students to be critical of the heresy and deviations of behavior, by using a clear and sincere heart to defend the truth, not blind fanaticism and hatred, with strong and scientific argumentation, not false analysis and delusions, with polite words and dignified, not with verbal abuse and complacency, also based on facts and accurate data, not hoaxes, false news and vicious slanders."

The quote is the statement of the Chairperson of the Santri Sidogiri Alumni Association Center to Haul Masyayikh Sidogiri in Jember on the 25th Ramadan 1439 H. Based on the description above, this account shows his views on the importance of using arguments that can be accounted for so that no one else can make each other expressions of hatred against each other that can threaten the integrity of the nation through theological propaganda that comes from fanaticism.

\section{Ala Santri: Producing Tolerance and Unity Theology Discourse}

The discourse developed by Ala Santri consists of a campaign of peaceful living with mutual respect and tolerance for differences, and internalization of religious values into the life of the nation-state. First, strengthening tolerance. Ala Santri's account is active in inviting tolerance. Among the messages conveyed by this account is an invitation to always learn about how polite and well-mannered and soothing.

In a post on August 15, 2017, Ala Santri's account wrote, "So students don't respect fellow students? What the world says! Then when will respect other people of different religions, 
ethnicities, and cultures? When will you respect your people?" From this post, it is clear that Ala Santri is campaigning for a harmonious, peaceful, tolerance and mutual respect for fellow children as a nature of life which is also important to fight for, especially in a country as diverse as Indonesia.

Second, the integration and internalization of religious values in the life of the nation and state. An understanding of the relationship between religion and state is one of the main factors for building peace in a country. Santri has an important role in the contextualization efforts of Islamic doctrine in the literature they study in the context of modern state administration. This challenge often faces obstacles, when some parties disagree and reject the foundation of the state on the pretext of religious texts. Thus, this contextualization effort found significance. In addition, students also play a role in the interpretation of the foundations of the state in the eyes of students. The hope, love for the country and efforts to build peace was born from religious awareness and beliefs.

Ala Santri's account emphasizes the importance of understanding and practicing the values of Pancasila as the noble values of a country. On October 1, 2018, which coincided with the day of the Pancasila Pact, the Ala Santri account posted a statement about the importance of understanding and practicing Pancasila. One of the most mentioned precepts is the Third Precept, Indonesian Unity. This account, emphasizes the importance of the Indonesian people to maintain the integrity of the Unitary Republic of Indonesia, namely with unity. The unity movement is echoed by inviting people to respect each other, helping each other (opening donations for disaster victims in Palu with the emphasis that there should not be discrimination due to religious factors) and so on. So that the motto of peaceful living, mutual tolerance is always voiced in this account.

\title{
Santri Gus Dur:Producing Universal Peace Discourse
}

Santri's social media accounts engaged in peacebuilding on social media with a strategy pattern of discourse production that narrates peace in a universal context are managed by the Gusdurian Network. According to this community's statement, there are many social media accounts that they manage, one of which is Santri Gus Dur,

\begin{abstract}
"We have more than 100 communities in various cities. We have Laskar Gusdurian Net, we have a working pattern, for example, this week we want to post what we will viral. We manage nationally the Gusdurian National Secretariat in Jogja. The narratives about peace, tolerance and pluralism are the main ones of the narratives that we hold. It is not specific to a particular issue that is polemic, or even to a certain person. We more often grounded Gus Dur's humanitarian ideas to millennial through social media and online. So, our discourse is not only about Islam, in the sense of Aswaja-NU versus Wahabi-Salafy doctrine. We are discussing anti-discrimination against minorities, for example, against Shiites. We want to unify the religious tolerance of the people universally. Our ideology is not as clear as other friends, who immediately declared their account of an NU affiliated account, and therefore the production of their discourse is to counter the propaganda and attacks of Wahaby." [7].
\end{abstract}

The aim of this account is to create a peaceful life, and prioritize unity and unity based on universal values when faced with casuistic issues that have the potential to divide the nation. Therefore, Santri Gus Dur's account, more raised humanitarian and peace discourses, such as; 
"Anugerah Nurani Kemanusiaan Bai Setiap Insan Manusia, Ngaji Kemanusiaan, Kemanusiaan dan Sebuah Batas, Kemanusiaan Gus Dur dalam Sehelai Kutang, and written by Gus Dur, such as "Sanggupkah Kita Mengabdi Kepada Kemanusiaan?," also a work by Alissa Wahid (Gus Dur's daughter) quoted by this account,

"Yes, every ruler has development priorities. There are always those who are 'sacrificed'. But the principles of justice, humanity, non-oppression must be our principles!” stated by Alissa Wahid.

Peacebuilding practiced by Santri Gus Dur's account above takes a form of a universal peace discourse production. Therefore, it can cover themes and issues relating to the efforts to create a peaceful life, namely humanity, religious pluralism, tolerance, local wisdom, compassion to eliminate hatred, brotherhood in the name of humanity, and politeness of expression.

\section{Conclusion}

Based on the thematic approach to peacebuilding, which uses 10 peacebuilding keywords, by obtaining data posting 3 santri social media accounts from 2015-2018, this study concluded that there are a variety of discourses in the practice of peacebuilding through discourse production strategies on social media that are pursued by 3 santri social media accounts, i.e.production of Aswaja theological discourse and anti-hate speech (Santri Sidogiri), production of tolerance and theology of unity (Ala Santri), and production of universal peace narratives (Santri Gus Dur).

There are some factors that encourage social media accounts of santri communities in seeking peacebuilding through social media, including their awareness in responding the contents of the Islamic teachings on social media which are already too dominated by antiAswaja doctrine, the understanding of religious radicalism, and the ideology of anti-Pancasila of Islamism and the ideas that did not reflect the teachings of friendly and peace-loving Islam.

\section{References}

[1] K. Robert V, Netnography: Doing Ethnographic Research Online. London: Sage, 2009.

[2] C. Geertz, Thick Description: Toward an Interpretive Theory of Culture In The interpretation of Cultures: Selected Essays. New York: Basic Books, 1973.

[3] V. Piia, Digital Ethnograpy dalam Tilburg Papers in Culture Studies, Paper 104. Tilburg: Tilburg Universit, 2014.

[4] K. Robert V, "Netnography: the Marketers's Secret Weapon: How Social Media Understand Drives Innovation.” p. 12, 2010.

[5] S. Hidayah, "Antropologi Digital dan Hiperteks: Sebuah Pembahasan Awal," RANAH, vol. II, no. 1. Universitas Gajah Mada, Yogyakarta, p. 6, 2012. 
[6] N. S. Ibrahim, Penelitian dan Penilaian Pendidikan. Bandung: Sinar Baru Algensindo, 2001.

[7] CJD, "Interview with the Central Java Gusdurian Network Media Division," Semarang, 2018. 